\title{
Wolbachia endosymbiont responsible for cytoplasmic incompatibility in a terrestrial crustacean: effects in natural and foreign hosts
}

\author{
Y. MORET†, P. JUCHAULT \& T. RIGAUD* \\ Université de Poitiers, Laboratoire de Génétique et Biologie des Populations de Crustacés, UMR CNRS 6556, \\ 40 avenue du Recteur Pineau, F-86022 Poitiers Cedex, France
}

\begin{abstract}
Wolbachia bacteria are vertically transmitted endosymbionts that disturb the reproduction of many arthropods thereby enhancing their spread in host populations. Wolbachia are often responsible for changes of sex ratios in terrestrial isopods, a result of the feminization of genotypic males. Here we found that the Wolbachia hosted by Cylisticus convexus $(w \mathrm{Cc})$ caused unidirectional cytoplasmic incompatibility (CI), an effect commonly found in insects. To understand the diversity of Wolbachiainduced effects in isopods, $w \mathrm{Cc}$ were experimentally transferred in a novel isopod host, Armadillidium vulgare. $w$ Cc conserved the ability to induce CI. However, Wolbachia were not transmitted to the eggs, so the capacity to restore the compatibility in crosses involving two transinfected individuals was lost. The feminizing Wolbachia hosted by $A$. vulgare was unable to rescue $\mathrm{CI}$ induced by $w \mathrm{Cc}$. These results showed that Wolbachia in isopods did not evolved broadly to induce feminization, and that CI and the feminizing effect are probably due to different mechanisms. In addition, $w \mathrm{Cc}$ reduces the mating capacity of infected $C$. convexus males, suggesting that the bacteria might alter reproductive behaviour. The maintenance of $w \mathrm{Cc}$ in host populations is discussed.
\end{abstract}

Keywords: crustacean, cytoplasmic incompatibility, endosymbiont, isopod, Wolbachia.

\section{Introduction}

Many invertebrates harbour intracellular bacteria of the genus Wolbachia (Werren \& O'Neill, 1997; Bandi et al., 1998). These maternally inherited symbionts cause various alterations in the reproduction of their hosts, which can enhance the spread of the infection in arthropod populations (review in Bourtzis \& O'Neill, 1998). The most common alteration is cytoplasmic incompatibility (CI). In diploids, CI results in a high rate of embryo mortality when the sperm of infected males fertilizes oocytes that are uninfected, or infected by another bacterial variant (review in Hoffmann \& Turelli, 1997). The compatibility is restored in crosses between two individuals infected with the same Wolbachia variant. The embryo mortality is caused by abnormalities of mitosis during the development (e.g. Callaini

*Correspondence. E-mail: thierry.rigaud@univ-poitiers.fr

$\nmid$ Present address: Eidgenössische Technische Hochschule (ETH) Zürich, Experimental Ecology, ETH-Zentrum, NW, CH-8092 Zürich, Switzerland. et al., 1996), probably caused by a Wolbachia-induced modification of sperm chromosomes. In compatible crosses, modified paternal chromosomes are rescued by the Wolbachia present in the eggs. Wolbachia bacteria also induce thelytokous parthenogenesis in a number of parasitoid wasps (Stouthamer et al., 1993), male-killing in some insects (Hurst et al., 1999), and convert genotypic males into phenotypic females in some terrestrial isopods (woodlice) (Martin et al., 1973; review in Rigaud, 1997).

The overall evolution of Wolbachia is difficult to understand, considering the diversity of the effects expressed by Wolbachia in their different hosts, the discrepancy between host and symbiont phylogenies, and the absence of correlation between Wolbachia phylogenetic position and their effects (Rousset et al., 1992; Werren et al., 1995; Van Meer et al., 1999). Horizontal transfers between species explain the distribution of Wolbachia (Werren et al., 1995; Vavre et al., 1999), but not the diversity of the effects between hosts. Recent studies argue that both Wolbachia strains and host characteristics explain the diversity in effects 
observed in insects (Poinsot et al., 1998; Hurst et al., 1999). However, data on Wolbachia plasticity, i.e. the ability (or not) of a given Wolbachia strain to express different effects in different hosts, are still scanty. Most available data are on interspecific transfers between hosts where Wolbachia express the same phenotype, and showed that the effects were conserved in the new host (e.g. Rousset \& De Strodeur, 1994; Braig et al., 1994; Rigaud \& Juchault, 1995). The only transfer made between hosts where Wolbachia have two different effects revealed that the transinfected symbionts did not induce reproductive alteration in their new host (Van Meer \& Stouthamer, 1999). However, in this case, the new infection was not stably maintained, suggesting that Wolbachia were not adapted to their new host.

In terrestrial isopods, Wolbachia infection is widespread. Most of the symbionts are closely related and belong to a monophyletic group (Bouchon et al., 1998). Nevertheless, they cause at least two phenotypes: CI in Porcellio dilatatus (Legrand et al., 1978; Rousset et al., 1992) and feminization in many other species (Martin et al., 1973; Juchault \& Legrand, 1979; Juchault et al., 1994; Rigaud et al., 1999). However, the effect expressed by some Wolbachia belonging to the 'isopod clade' is unknown. A better knowledge of the variable effects within this clade and the analysis of phenotype following experimental transinfection between woodlice species would help in understanding of Wolbachia evolution in this group. This study was undertaken to elucidate the effect of the Wolbachia strain harboured by the woodlouse Cylisticus convexus (thereafter called $w \mathrm{Cc}$ strain, following the nomenclature proposed by Zhou et al., 1998). Cylisticus convexus is closely related to woodlice species where feminization is expressed and $w$ Cc belong to the clade of feminizing symbionts. However, a previous study suggested that $w \mathrm{Cc}$ do not induce feminization (Bouchon et al., 1998). Here, we shown that $w \mathrm{Cc}$ cause $\mathrm{CI}$ in C. convexus. Experimental transspecific transfers were done to test whether this CI was conserved in the isopod Armadillidium vulgare, which is sensitive to Wolbachia-induced feminization by a different strain of Wolbachia.

\section{Materials and methods}

\section{Wolbachia infection in Cylisticus convexus}

Nine males and 13 females of Cylisticus convexus were found in 1995 at Avanton (Vienne, France) and one male and two females were found in 1998 at Villedaigne (Aude, France). Animals were reared (each sample separated) until gravid females were observed. These gravid females were isolated, allowed to release their offspring, and were then tested for the presence of
Wolbachia. Some offspring of the Avanton sample were used to assess the Wolbachia vertical transmission rate; others were kept to maintain the strain. Offspring from Villedaigne were first crossed, and then tested. Presence/ absence of Wolbachia was tested by PCR assays. Total DNA was extracted from the gonads and the nervous system, according to Bouchon et al. (1998). Specific primers for Wolbachia (99f-994r, O'Neill et al., 1992) were used to amplify the bacterial 16S rDNA gene and the amplification conditions were as previously described (Rousset et al., 1992). The presence/absence of PCR product determine the presence/absence of Wolbachia in the animal tested. In negative samples, a mitochondrial primer set was used to ensure the quality of the host's DNA, as described in Bouchon et al. (1998).

Pair crosses (male $\times$ female) of each of the four crossing types were made: $\mathrm{u} \times \mathrm{u}, \mathrm{u} \times w \mathrm{Cc}, w \mathrm{Cc} \times \mathrm{u}$, $w \mathrm{Cc} \times w \mathrm{Cc}$, where $\mathrm{u}$ denotes uninfected individuals (offspring of females collected at Villedaigne) and $w \mathrm{Cc}$ infected individuals (from the fourth generation of the Avanton strains). Average weights of females were not significantly different between the $\mathrm{u}$ and $w \mathrm{Cc}$ strains $(68.23 \mathrm{mg} \pm \mathrm{SE} 1.83$ and $69.79 \mathrm{mg} \pm 1.36$, respectively; $t=0.68, P=0.50$ ), allowing a comparison of their fertility. Mating occurred in small circular plastic boxes ( $8 \mathrm{~cm}$ diameter) at $20^{\circ} \mathrm{C}$ and under a LD $18: 6$ photoperiod to promote the onset of reproduction. Woodlice lay their eggs into a ventral incubating pouch (marsupium), where they are incubated for four weeks. The transparency of the marsupium allowed us to estimate the proportion of developing embryos during the third week of development. A total counting of the embryos was nevertheless impossible, as eggs are deposited in several layers in the marsupium and are not transparent. The offspring were isolated from their parents immediately after birth, and completed their development in larger rectangular boxes $(26 \times 13 \mathrm{~cm})$. Offspring were sexed and counted eight weeks after birth. The infection status of both sires and mothers was determined by PCR. The inseminate status of the females was verified by checking for sperm in the genital tracts. Statistical analyses were made using JMP 3.2 software (SAS Institute, 1997).

\section{Experimental horizontal transfers}

To test the effect of $w \mathrm{Cc}$ in another genetic context, these symbionts were injected into 30 males and 30 females of uninfected Armadillidium vulgare, a woodlouse, which is feminized by its endemic Wolbachia. Uninfected $A$. vulgare were from lines reared in the laboratory for 30 years (Nice, Alpes maritimes, France). Injections were made using homogenates of 13 
C. convexus females, each from a single iso-female infected line. Ovaries and nerve chords from these females were homogenized in $700 \mu \mathrm{L}$ Ringer solution and the resulting homogenate was passed through a $1.2-\mu \mathrm{m}$ pore membrane, which retains cell fragments but allows passage of Wolbachia endosymbionts (Rigaud et al., 1991). The cuticle of recipient animals was pierced using a fine needle, and $1 \mu \mathrm{L}$ of extract was injected using a thin glass needle adapted to a Hamilton syringe. The recipient individuals were reared separately for 24 weeks before mating. The uninfected brothers and sisters of inoculated individuals were used as reference. A control was made, consisting of seven uninfected males injected with Ringer solution only. Such a control was not made in females since previous experiments showed that such an injection had no effect on female reproduction (Rigaud et al., 1991). The same breeding procedure as described above for $C$. convexus was used for $A$. vulgare, but we did not count the number of developing embryos in the marsupium, and we sexed the offspring 12 weeks after birth.

Ten A. vulgare females naturally infected with $w$ Av (their native feminizing Wolbachia) were crossed with males injected with $w \mathrm{Cc}$ (the 10 males were some of those used in the preceding experiment). The females came from a strain collected at Celles-sur-Belle (Deux-Sèvres, France) in 1992 and maintained in the laboratory.

\section{Cytological investigations of embryonic development}

The first steps of the embryonic development of $C$. convexus and $A$. vulgare were examined in embryos stained with DAPI (4'-6 diamidine-2-phenylindole dihydrochloride). DAPI forms fluorescent complexes with double-stranded DNA, thereby staining chromosomes, which allows monitoring of mitosis. The staining was adapted to woodlice embryos according to Bressac \& Rousset's protocol (1993). Embryos from male $w \mathrm{Cc} \times$ female $\mathrm{u}$ crosses were removed from the incubating pouch, air dried, and fixed for $5 \mathrm{~min}$ in absolute ethanol. The embryos were dried, incubated in DAPI $(1 \mu \mathrm{g} / \mathrm{mL})$ for $15 \mathrm{~min}$, and rinsed with Ringer. The embryos were then placed on slides in $10 \%$ gelatine, and examined under a Zeiss Axoplan microscope equipped for epifluorescence. Embryos from male $\mathrm{u} \times$ female $\mathrm{u}$ crosses were checked as controls (from 10 to 20 embryos at each development stage mentioned in Table 3).

\section{Results}

\section{Natural Wolbachia infection in Cylisticus convexus}

All females found in Avanton were infected (Table 1). Among the 119 offspring tested, 94.1\% harboured Wolbachia, showing a high, but not complete, vertical transmission rate of the bacteria (Fisher exact test comparing the infection between males and females showed no significant difference, $P=0.11$ ). The two females from Villedaigne were not infected by Wolbachia. Their offspring tested afterwards confirmed the uninfected status of these lines (Table 1). There was no significant sex ratio deviation from 1:1 in the broods, whatever the infection status of the lineages (KruskalWallis test: $\chi_{1}^{2}=1.22 ; P=0.27$, for comparison between populations).

Despite the long duration of breeding experiments (pairs were maintained for at least one month before females laid their eggs), some females were not inseminated, or inseminated in only a single genital tractus (half-inseminated) (Table 2). A logistic regression testing for the effects of male and female infection on the insemination status of females revealed an effect of male infection (Likelihood-Ratio $\chi_{2}^{2}=21.43 ; P<0.0001$ ), but no effect of female infection (L-R $\chi_{2}^{2}=0.13$; $P>0.90)$, nor of the interaction (L-R $\chi_{2}^{2}=0.13$; $P>0.90)$. Infected males were therefore less successful at mating, irrespective of the infection status of their mate. A dissection of the males revealed neither abnormalities nor macroparasites in those that did not mate. The broods of non-inseminated or half inseminated females were excluded from further analysis (Table 2).

Among the fully inseminated females, there was a significant difference in the proportion of non-developing embryos in the marsupium according to the crossing type

Table 1 Sex ratios and Wolbachia infection in broods of Cylisticus convexus females caught gravid at two different locations

\begin{tabular}{|c|c|c|c|c|c|c|c|c|c|}
\hline Location & \multicolumn{2}{|c|}{ Mothers } & \multicolumn{7}{|c|}{ Offspring } \\
\hline Villedaigne & 2 & 0 & 39 & 42 & $47.7 \pm 1.8$ & 0 & 19 & 0 & 40 \\
\hline
\end{tabular}

i, infected by Wolbachia (positive PCR test); u, uninfected by Wolbachia (negative PCR test).

(C) The Genetics Society of Great Britain, Heredity, 86, 325-332. 
Table 2 Crosses between Cylisticus convexus and Armadillidium vulgare lineages infected or not by Wolbachia endosymbionts

\begin{tabular}{|c|c|c|c|c|c|c|c|c|}
\hline Species & $\begin{array}{l}\text { Cross type } \\
(\text { male } \times \text { female })\end{array}$ & $N$ & N0 & $N 1$ & $N 2$ & $\begin{array}{l}\text { Mean proportion } \\
\text { of dead embryos } \\
\text { per brood } \pm \text { SE } \dagger \\
\text { (embryos counted) } \ddagger\end{array}$ & $\begin{array}{l}\text { Mean number } \\
\text { of offspring per } \\
\text { brood } \pm \text { SE } \dagger \\
\text { (total offspring) }\end{array}$ & $\begin{array}{c}\text { Mean proportion } \\
\text { of males per } \\
\text { brood } \pm \mathrm{SE} \dagger \\
\text { (total males) }\end{array}$ \\
\hline \multirow[t]{4}{*}{ C. convexus } & $w \mathrm{Cc} \times w \mathrm{Cc}$ & 18 & 6 & 2 & 10 & $\begin{array}{l}0.02 \pm 0.01 \\
(193)\end{array}$ & $\begin{array}{l}23.5 \pm 1.6 \\
(235)\end{array}$ & $\begin{array}{l}0.51 \pm 0.03 \\
(118)\end{array}$ \\
\hline & $w \mathrm{Cc} \times \mathrm{u}$ & 20 & 8 & 1 & 11 & $\begin{array}{l}0.51 \pm 0.05 \\
(230)\end{array}$ & $\begin{array}{l}15.7 \pm 1.7 \\
(173)\end{array}$ & $\begin{array}{l}0.40 \pm 0.05 \\
(78)\end{array}$ \\
\hline & $\mathrm{u} \times w \mathrm{Cc}$ & 19 & 0 & 2 & 17 & $\begin{array}{l}0.05 \pm 0.02 \\
(299)\end{array}$ & $\begin{array}{l}22.6 \pm 1.3 \\
(385)\end{array}$ & $\begin{array}{l}0.48 \pm 0.02 \\
(188)\end{array}$ \\
\hline & $\mathrm{u} \times \mathrm{u}$ & 21 & 0 & 2 & 19 & $\begin{array}{l}0.02 \pm 0.01 \\
(309)\end{array}$ & $\begin{array}{l}23.8 \pm 1.8 \\
(452)\end{array}$ & $\begin{array}{l}0.49 \pm 0.02 \\
(220)\end{array}$ \\
\hline \multirow[t]{4}{*}{ A. vulgare } & $w \mathrm{Cc} \times w \mathrm{Cc}$ & 14 & 0 & 0 & 14 & - & $\begin{array}{l}7.6 \pm 3.3 \\
(107)\end{array}$ & $\begin{array}{l}0.35 \pm 0.01 \\
(49)\end{array}$ \\
\hline & $\mathrm{u} \times \mathrm{u}$ & 10 & 0 & 0 & 10 & - & $\begin{array}{l}92.3 \pm 8.8 \\
(923)\end{array}$ & $\begin{array}{l}0.49 \pm 0.00 \\
(446)\end{array}$ \\
\hline & $\mathrm{R} \times \mathrm{u}$ & 7 & 0 & 1 & 6 & - & $\begin{array}{l}88.5 \pm 6.4 \\
(531)\end{array}$ & $\begin{array}{l}0.50 \pm 0.01 \\
(266)\end{array}$ \\
\hline & $w \mathrm{Cc} \times w \mathrm{Av}$ & 10 & 0 & 0 & 10 & - & 0 & - \\
\hline
\end{tabular}

wAv, infected by Wolbachia of A. vulgare; $w \mathrm{Cc}$, infected by Wolbachia of C. convexus; $\mathrm{u}$, uninfected; R, males injected with Ringer solution; $N$, number of crosses; $N 0$, number of females not inseminated; $N 1$, number of females half inseminated; $N 2$, number of females fully inseminated.

$\uparrow$ Measures made on fully inseminated females only.

\$The number of embryos counted was often smaller than the total offspring because not all embryos could be counted in the marsupium (see methods).

(Table 2, Kruskal-Wallis test: $\chi_{3}^{2}=31.53 ; P<0.0001$ ). Crossing type male $w \mathrm{Cc} \times$ female $\mathrm{u}$ showed higher rates of non-developing eggs when compared to all other crossing types (Tukey test, $P<0.0001$ in all cases), while other crossing types did not differ significantly from each other $(P>0.80$ for each other comparisons). The result is a lower number of adult offspring from the male $w \mathrm{Cc} \times$ female $\mathrm{u}$ crossing type (Table 2, ANova: $F_{3,53}=4.19 ; \quad P=0.01$; Fisher PLSD post-hoc test: $P<0.03$ for comparisons between male $w \mathrm{Cc} \times$ female u group with all others; $P>0.50$ for other comparisons). There was no differences in the sex ratio of broods produced in the different crossing types (Table 2, Kruskal-Wallis test: $\left.\chi_{3}^{2}=4.67 ; P=0.20\right)$.

\section{Experimental horizontal transfers of $w C c$ into Armadillidium vulgare}

Twelve inoculated males and 11 inoculated females were tested by PCR, and were shown to harbour Wolbachia. None of the five control males tested was infected. None of the $A$. vulgare recipient males were feminized
20 weeks after inoculation with $w \mathrm{Cc}$, and they were therefore used for crosses.

Unlike in $C$. convexus, nearly all females were inseminated (Table 2). The broods of females mated with inoculated males were much smaller than broods sired by uninfected males, whatever the inoculation status of the females (Table 2; Kruskal-Wallis test: $\chi_{3}^{2}=33.06 ; P<0.0001$; Tukey post-hoc pairwise test significant $[P<0.0001]$ for the differences between broods from inoculated and uninfected males). No reproductive alteration was observed in crosses involving males injected with Ringer, when compared with crosses with no injection (Table 2; ANOva testing a difference in the number of offspring: $F_{1,14}=0.09$; $P>0.70)$. The reproductive alteration was therefore not due to the injection itself, but was correlated with male infection. Some females produced a second brood, and the results were the same as in the first (results not shown).

PCR tests on one male and one female offspring from broods of inoculated females revealed no Wolbachia (44 individuals tested). The maximum probability of any 
Wolbachia infection in this negative sample is 0.06 according to the estimation method of Post \& Millest (1991), and a comparison with the transmission rate of $w \mathrm{Cc}$ in $C$. convexus showed a highly significant difference (Fisher exact test, $P<0.0001$ ). The $w$ Cc transmission from transinfected mothers to their offspring was therefore unlikely or at least very low compared to that in the native host. This result is consistent with those obtained previously on experimental transfers in isopods: the Wolbachia transmission is inefficient after transfers between phylogenetically distant species. This contrasts with high transmission efficiency when transfers are made within the same species or between closely related species (between 86 and $100 \%$ as computed from data in Legrand \& Juchault, 1970; Rigaud \& Juchault, 1995). Wolbachia infection in mothers had no effect on the sex ratio of the broods (Kruskal-Wallis test: $\left.\chi_{3}^{2}=3.68 ; P>0.25\right)$, and the slight excess of females in the crosses male $w \mathrm{Cc} \times$ female $w \mathrm{Cc}$ (Table 3 ) was probably a bias due to the small number of offspring.

Ten A. vulgare females naturally infected with their feminizing wAv Wolbachia were crossed with males injected with $w \mathrm{Cc}$ (Table 2). None of these naturally infected A. vulgare females produced viable embryos, while dissection showed that the males had inseminated the females. Here the incompatibility was therefore total.

\section{Cytological investigations of embryonic development}

A total of 211 and 120 embryos from male $w \mathrm{Cc} \times$ female $\mathrm{u}$ crosses were examined in eight crosses of C. convexus and four crosses of $A$. vulgare, respectively. In both species, these embryos showed a similar increasing disturbance of mitosis (Table 3). The alterations did not occur during the first mitosis, as it is the case in some insects (Reed \& Werren, 1995), but appeared gradually after two or three cycles of cell divisions. The chromosomes did not segregate normally in anaphase, and bridges of DNA were visible between the two sets of dividing chromosomes, often generating parachute-like figures (Fig. 1b). Then, this DNA condensed and dispersed into the cytoplasm (Fig. 1c). A similar CI pattern occurred in embryos of Drosophila simulans reported by Callaini et al. (1996), where some of the chromosomes did not attach properly to the kinetochore microtubules. These abnormalities were also similar to those observed in Nasonia (Reed \& Werren, 1995), but at later mitotic stages. No mitotic divisions could be observed in abnormal embryos of $A$. vulgare $50 \mathrm{~h}$ after fertilization (stage $>64$ cells). In C. convexus, death of embryos occurred as late as the segmentation stage (Table 3). In most dead embryos, nuclei were very diffuse, and the cytoplasm became stained with DAPI,

Table 3 Chronology of mitotic disorders during the development of Cylisticus convexus and Armadillidium vulgare embryos from male $w \mathrm{Cc} \times$ female $\mathrm{u}$ crosses

\begin{tabular}{|c|c|c|c|c|c|c|}
\hline \multirow[b]{3}{*}{ Species } & \multirow[b]{3}{*}{$t$} & \multirow{3}{*}{$\begin{array}{l}\text { Development in } \\
\text { male } \mathrm{u} \times \text { female } \mathrm{u} \\
\text { crosses }\end{array}$} & \multicolumn{4}{|c|}{ Development in male $w \mathrm{Cc} \times$ female $\mathrm{u}$ crosses } \\
\hline & & & \multirow{2}{*}{$\begin{array}{c}\text { Normal } \\
\text { embryos } \\
n\end{array}$} & \multicolumn{3}{|c|}{$\begin{array}{l}\text { Embryos with abnormal divisions (AD) } \\
\text { or dead embryos }\end{array}$} \\
\hline & & & & $n$ & $\begin{array}{c}\text { Stage of } \\
\text { development }\end{array}$ & $\begin{array}{l}\% \text { cells with } \\
\text { AD }(n)^{*}\end{array}$ \\
\hline \multirow{10}{*}{ Cylisticus convexus } & $12 \mathrm{~h}$ & $1-2$ cells & 35 & 0 & - & - \\
\hline & $24 \mathrm{~h}$ & $2-4$ cells & 10 & 5 & 4 cells & $25.0 \%(20)$ \\
\hline & $50 \mathrm{~h}$ & $32-64$ cells & 8 & 1 & 64 cells & $4.7 \%(64)$ \\
\hline & & & & 11 & $32 \leq$ cells $\leq 64$ & $38.7 \%(88)$ \\
\hline & & & & 2 & Cells $<32$ & $54.0 \%(28)$ \\
\hline & $25 \mathrm{~d}$ & Full embryo & 72 & 24 & $8 \leq$ cells $\leq 250$ & n.d. \\
\hline & & & & 33 & Cells $>250$ & n.d. \\
\hline & & & & 2 & Cells $>1000$ & n.d. \\
\hline & & & & 5 & Segmentation & n.d. \\
\hline & & & & 3 & n.d. & n.d. \\
\hline \multirow[t]{4}{*}{ Armadillidium vulgare } & $12 \mathrm{~h}$ & $1-2$ cells & 30 & 0 & - & - \\
\hline & $24 \mathrm{~h}$ & $2-4$ cells & 2 & 28 & 4 cells & $35.7 \%(112)$ \\
\hline & $60 \mathrm{~h}$ & $32-64$ cells & 0 & 30 & $20<$ cells $\leq 64$ & $100 \%(100)$ \\
\hline & $25 \mathrm{~d}$ & Full embryo & 1 & 29 & Cells $\leq 64$ & n.d. \\
\hline
\end{tabular}

${ }_{w C c}$, infected by Wolbachia of C. convexus; u, uninfected; $t$, time after laying (in hours or days); n.d., not possible to determine due to DNA lysis in the embryos.

* $(n)$, number of cells where abnormal divisions were examined.

(C) The Genetics Society of Great Britain, Heredity, 86, 325-332. 

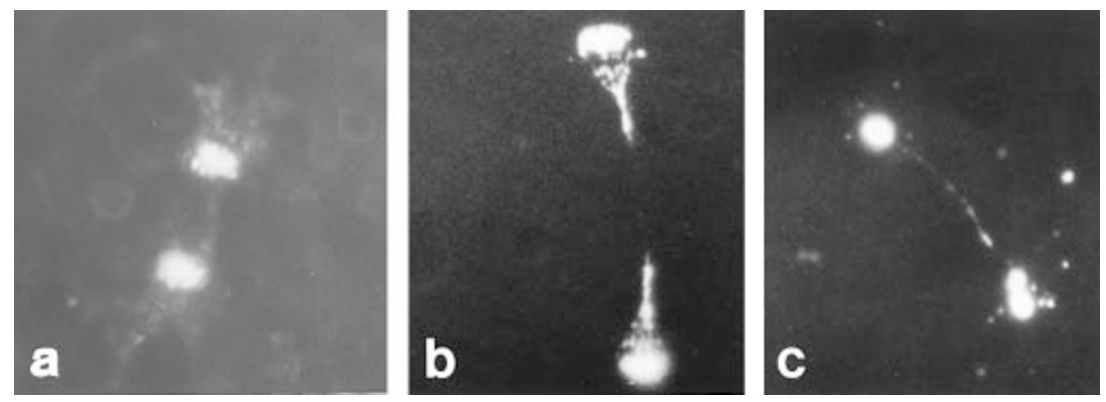

Fig. 1 Chromosomes (stained with DAPI) during the first steps in the development of woodlice embryos: (a) mitosis (anaphase) in an Armadillidium vulgare embryo from the control cross: male $\mathrm{u} \times$ female $\mathrm{u}, 38 \mathrm{~h}$ after fertilization $(\times 400)$; (b) abnormal mitosis (anaphase) in an $A$. vulgare embryo from the cross: male $w \mathrm{Cc} \times$ female $\mathrm{u}, 40 \mathrm{~h}$ after fertilization $(\times 400)$; (c) abnormal mitosis (anaphase) in a C. convexus embryo from the cross: male $w \mathrm{Cc} \times$ female $\mathrm{u}, 40 \mathrm{~h}$ after fertilization $(\times 400)$.

as if the DNA had gradually diffused into the cytoplasm. In control crosses, none of these abnormalities was observed. Furthermore, unfertilized eggs do not develop in isopods (Rigaud, personal observation). Therefore, abnormal mitosis observed in male $w \mathrm{Cc} \times$ female $u$ crosses cannot be explained by unfertilized eggs in these crosses.

\section{Discussion}

The experimental crosses showed that Wolbachia of $C$. convexus $(w \mathrm{Cc})$ did not cause feminization or malekilling in their natural host. They nevertheless caused embryo mortality in crosses between infected males and uninfected females, due to abnormal mitosis during embryo development. This pattern is similar to the unidirectional cytoplasmic incompatibility (CI) that occurs in several insect species (Hoffmann \& Turelli, 1997). This $w$ Cc-induced CI was moderate, since only half of the embryos died during their development. The $w \mathrm{Cc}$ transmission was imperfect but high, and, in compatible crosses, no difference in fertility between infected and uninfected females was detected (our experimental procedure did not allow fecundity estimations). These parameters, showing the infection success of this bacterial strain in its common host, may indicate that the Wolbachia infection in C. convexus is not recent (Turelli, 1994).

CI-inducing Wolbachia found in isopods (both $w \mathrm{Cc}$ and Wolbachia harboured by Porcellio dilatatus) belong to the monophyletic group of feminizing Wolbachia, a group well separated from those including CI-inducing Wolbachia hosted by insects (Bouchon et al., 1998). The presence of a second CI-inducing symbiont in the isopod Wolbachia clade indicates that Wolbachia infecting isopods have not evolved broadly to induce feminization. Trans-infection experiments in the novel host A. vulgare showed that (i) $w \mathrm{Cc}$ did not induce feminization, (ii) $w \mathrm{Cc}$ maintained CI expression in a different genetic context, and (iii) feminizing Wolbachia of $A$. vulgare were unable to rescue the CI induced by $w \mathrm{Cc}$. This means that different selective pressures have led isopod Wolbachia to evolve toward feminization or toward CI, and that the two effects induced by closely related symbionts are due to different mechanisms. Little is known about differences on sex differentiation between species in terrestrial isopods. However, differences exist in the androgenic hormones (a potential target of the Wolbachia feminizing effect) between different woodlice species (Martin \& Juchault, 1999). This could explain why some symbionts are unable to induce feminization in some species. But differences could also exist in life history traits, e.g. differences in the constraint due to the lack of males in the context of feminization (Hatcher et al., 1999).

In the new $A$. vulgare host, compatibility was not restored in crosses between transinfected males and females. This result may be explained by the very low vertical transmission rate to offspring by transinfected females, i.e. Wolbachia may not have reached the eggs, where rescue of compatibility occurs (Hoffmann \& Turelli, 1997; Bourtzis \& O'Neill, 1998). Therefore, $w$ Cc seems to be unadapted to the host $A$. vulgare.

Our results also suggest that $w \mathrm{Cc}$ lowers mating capacity of infected $C$. convexus males. As the males were kept for a long time with females for mating, and as dissection of these males did not show any evidence of physiological alteration, it is likely that Wolbachia cause an alteration in reproductive behaviour. However, a recent study showed that males of Drosophila simulans produce less sperm and are less fertile than uninfected ones (Snook et al., 2000). Our study did not allowed sperm counting, but such a screening could be a promising way to extent our observations.

Mating with infected males is required to induce $\mathrm{CI}$ in uninfected females. A low mating rate of these males would therefore potentially decrease the spreading 
capacity of Wolbachia in host populations, especially when the infection is rare. The moderate CI expression and the imperfect Wolbachia transmission to offspring would not help the symbiont spreading either (Hoffmann \& Turelli, 1997). By using our parameters estimates in Hoffman \& Turelli's model ( $\mu$, the fraction of uninfected offspring produced by infected females $=$ $0.059 ; H$, the relative hatch rate from incompatible vs. compatible crosses $=0.5 ; F$, the relative fecundity of infected females $=1$ ), we showed that $F(1-\mu)<1$, so that drift is required for the infection to be maintained locally. Several aspects of the host population dynamics support maintenance of $C$. convexus infection by drift. Populations are very scattered in France, and animals are generally found in low numbers in the wild (Vandel, 1962) as illustrated by our very small sample sizes. As discussed by Hoffmann \& Turelli (1997), drift could favour the fixation of CI-inducing symbionts in small populations, by pushing their frequency above the threshold required for a deterministic spreading to occur. Thus Wolbachia maintenance may be favoured in small populations of $C$. convexus, despite moderate CI expression, incomplete vertical transmission to offspring and Wolbachia effect on male reproductive success. On the other hand, drift could also easily induce local losses of Wolbachia in small populations. Owing to the rare data on wild populations of C. convexus, further studies are needed to understand the dynamics and distribution of Wolbachia in this isopod.

\section{Acknowledgements}

Animals from Villedaigne were collected by Gilbert Martin. Robert Comte provided efficient help with the rearing. Many thanks to Sylvain Charlat and Hervé Merçot for helpful discussions and comments on the manuscript. Cytological observations were made at the SIMIS (Service Interdisciplinaire de Microscopie et d'Imagerie Scientifique), University of Poitiers.

\section{References}

BANDI, C., ANDERSON, T. J. C., GENShI, G. AND BlAXTER, M. L. 1998. Phylogeny of Wolbachia in filarial nematodes. Proc. $R$. Soc. B, 265, 2407-2413.

BOUCHON, D., RIGAUD, T. AND JUCHAULT, P. 1998. Evidence for widespread Wolbachia infection in isopod crustaceans: molecular identification and host feminization. Proc. $R$. Soc. B, 265, 1081-1090.

BOURTZIS, K. AND O'NEILL, S. L. 1998. Wolbachia infection and arthropod reproduction. BioScience, 48, 287-293.

BRAIG, H. R., GUZMAN, H., TESH, R. R. AND O'NEILL, S. L. 1994. Replacement of the natural Wolbachia symbiont of Dro- sophila simulans with a mosquito counterpart. Nature, 367, 453-455.

BRESSAC, C. AND ROUSSET, F. 1993. The reproductive incompatibility system in Drosophila simulans: DAPI-staining analysis of the Wolbachia symbionts in sperm cysts. J. Invert. Pathol., 63, 226-230.

CALlAini, G., RIPARBELli, M. G., GIORDANO, R. AND DALlAI, R. 1996. Mitotic defects associated with cytoplasmic incompatibility in Drosophila simulans. J. Invert. Pathol., 67, 55-64.

HATCHER, M. J., TANEYHILl, D. E., DUNN, A. M. AND TOFTS, C. 1999. Population dynamics under parasitic sex ratio distortion. Theor. Pop. Biol., 56, 11-28.

hofFMANN, A. A. AND TURelli, M. 1997. Cytoplasmic incompatibility in insects. In: O’Neill, S. L., Hoffmann, A. A. and Werren, J. H. (eds) Influential Passengers: Inherited Microorganisms and Arthropod Reproduction, pp. 42-80. Oxford University Press.

HURST, G. D. D., JIGGINS, F. M., SCHULENBURG, J. H. G., BERTRAND, D. ET AL. 1999. Male-killing Wolbachia in two species of insects. Proc. R. Soc. B, 266, 735-740.

JUChAult, P. AND LEGRAND, J. J. 1979. Analyse génétique et physiologique de la détermination du sexe dans une population du crustacé isopode onisco Armadillidium nasatum (Budde-lund). Arch. Zool. Exp. Gén., 120, 24-43.

JUCHAUlt, P., FRELON, M., BOUCHON, D. AND RIGAUd, T. 1994. New evidence for feminizing bacteria in terrestrial isopods: evolutionary implications. C. R. Acad. Sci. Paris Life Sciences, 317, 225-230.

LEGRAND, J. J. AND JUCHAult, P. 1970. Modification expérimentale de la proportion des sexes chez les crustacés isopodes terrestres: induction de la thélygénie chez Armadillidium vulgare Latr. C. R. Acad. Sci. Paris Series D, 270, 706-708.

LEGRAND, J. J., MARTIN, G. AND ARTAUlt, J.C. 1978. Corrélation entre la présence d'un symbiote bactérien dans les ovocytes de Porcellio dilatatus petiti, et la stérilité du croisement $P$. $d$. petiti mâle $\times$ P. d. dilatatus femelle. Arch. Inst. Pasteur Tunis, 55, 507-514.

MARTIN, G. AND JUCHAUlt, P. 1999. Androgenic hormone specificity in terrestrial isopods (Oniscidea): systematic involvements. J. Crust. Biol., 19, 684-689.

MARTin, G., JUChaUlt, P. AND Legrand, J. J. 1973. Mise en évidence d'un micro-organisme intracytoplasmique symbiote de l'Onisco Armadillidium vulgare L., dont la présence accompagne l'intersexualité ou la féminisation totale des mâles génétiques de la lignée thélygène. C. R. Acad. Sci. Paris III, 276, 2313-2316.

O'NEILl, S. L., GIORDANO, R., COLBERT, A. M. E., KARR, T. L. $E T A L$. 1992. 16S rDNA phylogenetic analysis of the bacterial endosymbionts associated with cytoplasmic incompatibility in insects. Proc. Natl. Acad. Sci. U.S.A., 89, 2699-2702.

POINSOT, D., BOURTZIS, K., MARKAKIS, G., SAVAKIS, C. ET AL. 1998. Wolbachia transfer from Drosophila melanogaster into D. simulans: host effect and cytoplasmic incompatibility relationships. Genetics, 150, 227-237.

POST, R. J. AND MILLEST, A. L. 1991. Sample size in parasitological and vector surveys. Parasitol. Today, 7, 141. 
REED, K. M. AND WERREN, J. H. 1995. Induction of paternal genome loss by the paternal sex ratio chromosome and cytoplasmic incompatibility bacteria (Wolbachia): a comparative study of early embryonic events. Mol. Reprod. Devel., 40, 408-418.

RIGAUD, T. 1997. Inherited microorganisms and sex determination of arthropod hosts. In: O'Neill, S. L., Hoffmann, A. A. and Werren, J. H. (eds) Influential Passengers: Inherited Microorganisms and Arthropod Reproduction, pp. 81-101. Oxford University Press.

RIGAUD, T. AND JUCHAUlT, P. 1995. Success and failure of horizontal transfers of feminizing Wolbachia endosymbionts in woodlice. J. Evol. Biol., 8, 249-255.

RIGAUd, T., SOUTY-Grosset, C., RAIMOND, R., MOCQUARD, J. P. ET $A L$. 1991. Feminizing endocytobiosis in the terrestrial crustacean Armadillidium vulgare Latr. (Isopoda): recent acquisitions. Endocytobiosis Cell Res., 7, 259-273.

RIGAUD, T., MOREAU, J. AND JUCHAUlt, P. 1999. Wolbachia infection in the terrestrial isopod Oniscus asellus: sex ratio distortion and effect on fecundity. Heredity, 83, 469-475.

Rousset, F. AND DE STROdeur, E. 1994. Properties of Drosophila simulans strains experimentally infected by different clones of the bacterium Wolbachia. Heredity, 71, 325-331.

Rousset, F., BOUChON, D., PINTUREAU, B., JUChaUlt, P. ET AL. 1992. Wolbachia endosymbionts responsible for various alterations of sexuality in arthropods. Proc. R. Soc. B, 250, 91-98.

SNOOK, R. S., ClELAND, S. Y., WOLFNER, M. F. AND KARR, T. L. 2000. Offsetting effects of Wolbachia infection and heat shock on sperm production in Drosophila simulans: analyses of fecundity, fertility and accessory gland proteins. Genetics, 155, 167-178.
STOUTHAMER, R., BREEUWER, J. A. J., LUCK, R. F. AND WERREN, J. H. 1993. Molecular identification of microorganisms associated with parthenogenesis. Nature, 361, 66-68.

TURELLI, M. 1994. Evolution of incompatibility-inducing microbes and their hosts. Evolution, 48, 1500-1513.

VANDEL, A. 1962. Faune de France. 64, isopodes terrestres. P. Chevalier, Paris.

VAN MEER, M. M. M. AND STOUTHAMER, R. 1999. Cross-order transfer of Wolbachia from Muscidifurax uniraptor (Hymenoptera: Pteromalidae) to Drosophila simulans (Diptera: Drosophilidae). Heredity, 82, 163-169.

VAN MEER, M. M. M., WITTEVELDT, J. AND STOUTHAMER, R. 1999. Phylogeny of the arthropod endosymbiont Wolbachia besed on wsp gene. Insect Mol. Biol., 8, 399-408.

VAVRe, F., FleUry, F., LEPETIT, D., FOUILlet, P. ET AL. 1999. Phylogenetic evidence for horizontal transmission of $\mathrm{Wol}$ bachia in host-parasitoid associations. Mol. Biol. Evol., 16, 1711-1723.

WERREN, J. H. AND O'NEILL, S. L. 1997. The evolution of heritable symbionts. In: O’Neill, S. L., Hoffmann, A. A. and Werren, J. H. (eds) Influential Passengers: Inherited Microorganisms and Arthropod Reproduction, pp. 1-41. Oxford University Press.

WERREN, J. H., ZHANG, W. AND GUO, L. R. 1995. Evolution and phylogeny of Wolbachia: reproductive parasites of arthropods. Proc. R. Soc. B, 261, 55-71.

ZHOU, W. F., ROUSSET, F. AND O'NEILL, S. L. 1998. Phylogeny and PCR based classification of Wolbachia strains using wsp gene sequences. Proc. R. Soc. B, 265, 509-515. 